\title{
Effect of Urea Intake on Water Intake, Urine Volume and Some Urinary Mineral Levels in Sheep
}

\author{
Haruhiko Watanabe, Akira Miyazaki and Ryoji Kawashima \\ College of Agriculture, Kyoto University, Kyoto-shi 606
}

(Received July 3, 1975)

\begin{abstract}
The object of this experiment was to study the effect of urea intake on water intake, urine volume and some urinary mineral levels in sheep to know the effect of urea intake on the occurrence of urolithiasis in ruminants on high concentrate ration. Six adult wethers were allotted to two uniform lots (soy-protein lot and urea lot) and were used in $2 \times 2$ factorial design trials. Each trial involved a 14-day preliminary period followed by a 10-day fecal and urinary collection period. During the collection period, water intake, urine volume, fecal moisture, urinary $\mathrm{pH}$, urinary osmotic pressure and urinary $\mathrm{Ca}, \mathrm{Mg}$ and $\mathrm{P}$ were determined. Experimental data were evaluated statistically by analysis of variance performed among groups, treatments and periods. Urine volume per metabolic body size was significantly greater $(131 \%, \mathrm{P}<.05)$ in the urea-fed animals than in the soy-protein-fed animals. Similar but non-significant increase was found on water intake (117\%) in the animals which received urea ration. However, no difference was observed on fecal moisture, urinary osmotic pressure, Hematocrit and urinary $\mathrm{pH}$, urinary $\mathrm{Ca}$ and $\mathrm{P}$ levels between the treatments. Urinary $\mathrm{Mg}$ level in the urea-fed animals was lower than that of the soy-protein-fed animals. The results suggested that effect of urea intake on the prevention of urolithiasis seemed to be introduced by the increased excretion of urine and not by other factors such as the changes of urinary $\mathrm{pH}$ or urinary levels of minerals. The relationship between water intake and urine volume in this experiment was known to be described in the following equation; U.V.= 0.189 W. I. +68.97 , where U.V. and W.I. = urine volume $(\mathrm{ml})$ and water intake $(\mathrm{m} l)$ per metabolic body size of the animals per day.
\end{abstract}

The great majority of work on feeding urea-ration to ruminants has dealt with the efficiency of urea utilization as a protein substitute ${ }^{1)}$. Some workers ${ }^{2)}$ observed, unexpectedly, that urea intake seemed to be effective in the prevention of urolithiasis in fattening steer on high concentrate ration. They supposed that it was due to high intake of drinking water followed by volumetric increase of excretion of urine in the urea-fed animals ${ }^{2}$. However, though urea was known to be effective in diuresis in non-ruminant animals ${ }^{3)}$, the mechanism of the prevention of urolithiasis by urea intake in ruminants was not apparent. Minerals such as calcium, magnesium and phosphorus in the ration were also known to have influences on the occurrence of urolithiasis in ruminants ${ }^{4}$. However, no report seemed to be available, so far as the authors knew, to show the effect of urea intake on mineral metabolism of ruminants. The object of this experiment was to study the effect of urea intake on water intake, urine volume and some urinary mineral levels in sheep. 


\section{Experimental procedure}

Six adult Japanese Corriedale-Suffolk $F_{1}$ wethers, about $45 \mathrm{~kg}$ in body weight, were used in this experiment. They were allotted to two uniform treatment lots, each lot containing three animals, and were used in $2 \times 2$ factorial design trials. Each trial involved a 14-day preliminary period followed by a 10-day fecal and urinary collection period. The animals were kept in metabolism crates and received $400 \mathrm{~g}$ of the rations shown in Table 1 twice daily. Water was available at all times.

The animals allotted to the soy protein lot received the isolated soy ration at 9:00 a.m. and 4:00 p. m. Those allotted to the urea lot also received the urea ration. During the collection period, water intake and urine volume were measured and fecal moisture, urinary $\mathrm{pH}$, urinary osmotic pressure and some urinary minerals such as calcium, magnesium and phosphorus were determined. On the last day of each collection period, samples of blood were taken three hours after the morning feeding. The hematocrit value of the blood was determined using Wintrobe tube ${ }^{5)}$. Water intake, urine volume and fecal moisture were determined by the usual method ${ }^{6)}$.

The $\mathrm{pH}$ of fresh urine was determined by $\mathrm{pH}$ paper (Toyoroshi Co. Ltd.). Urinary osmotic pressure was determined by the method of cryoscopy ${ }^{7}$. Urinary calcium and magnesium analy. ses were made with an atomic absorption spectrophotometer after ashing with nitric and perchloric acids. Phosphorus was determined by the method of Fiske-Subbarow ${ }^{8}$ ). Experimental data

Table 1. Composition of the experimental rations

\begin{tabular}{ccc}
\hline \hline Item & Isolated soy ration & Urea ration \\
\hline Ingredients & $25.00 \%$ & $25.00 \%$ \\
Timothy hay & 69.24 & 71.49 \\
Ground barley & 4.50 & 2.25 \\
Isolated soy protein & - & 0.38 \\
Urea (N: 46.6\%) & 0.38 & 0.88 \\
$\mathrm{NaCl}$ & 0.88 & 100.00 \\
$\mathrm{CaCO}_{3}$ & 100.00 & \\
Total & & $13.53 \%$ \\
Chemical analysis & $13.24 \%$ & 16.83 \\
Moisture & 14.11 & 2.08 \\
Crude protein & 2.04 & 51.70 \\
Crude fat & 54.68 & 11.30 \\
Nitrogen free extract & 11.20 & 4.56 \\
Crude fiber & 4.73 & $0.69 \%$ \\
Crude ash & & 0.15 \\
Mineral analysis & $0.68 \%$ & 0.38 \\
Calcium & 0.16 & \\
Magnesium & 0.42 & \\
Phosphorus & &
\end{tabular}




\section{Watanabe, Miyazaki and KaWashima}

were evaluated statistically by analysis of variance performed among groups, treatments and periods, according to the method outlined by YosHiDA ${ }^{9)}$.

\section{Results}

The results of analysis of variance for water intake, urine volume and fecal moisture calculated on the basis of metabolic body size $\left(\mathrm{BW}_{\mathrm{kg}}^{0.75}\right)$ and the average values for each treatment are shown in Table 2.

Analysis clearly indicated that variance ratios of periods for water intake and urine volume were much greater $(P<.01)$ than those of groups and treatments. Significant difference $(P<.05)$ was also observed between the groups in urinary volume and fecal moisture, and between the treatments in urine volume. Though no significant difference was observed between the treatments, water intake per metabolic body size was much greater in the urea-fed animals. Urine volume increased significantly $(P<.05)$ when urea ration was given to the animals. However, no difference of fecal moisture was observed between soy protein and urea treatments.

The results of analysis of variance for urinary osmotic pressure and hematocrit value, and the average values for each treatment are shown in Table 3. The average urinary $\mathrm{pH}$ for each treatment, which was available only in period 2 , is also shown in this table.

Analysis of variance indicated that there was no significant difference in urinary osmotic pressure and hematocrit value among the groups, treatments and the periods respectively. Average urinary osmotic pressure of the urea-fed animals was almost equal, but, average hematocrit value was slightly higher for the urea-fed animals. Urinary $\mathrm{pH}$ was considerably higher in the ureafed animals than in the animals that received the isolated soy ration, with large standard deviation respectively.

The results of analysis of variance for urinary levels of calcium, magnesium and phosphorus and the average values for each treatment are shown in Table 4.

Analysis indicated that variance ratios of periods for urinary levels of magnesium and phosphorus were much greater $(P<.01)$ than those of the groups and the treatments. However, no significant difference was observed on urinary levels of calcium, magnesium and phosphorus between soy protein and urea treatments. It was remarked that average urinary level of mag-

Table 2. Analysis of variance of water intake, urine volume and fecal moisture

\begin{tabular}{|c|c|c|c|c|c|c|c|}
\hline \multirow{2}{*}{$\begin{array}{l}\text { Source of } \\
\text { variation }\end{array}$} & \multirow[b]{2}{*}{ d.f. } & \multicolumn{2}{|c|}{$\begin{array}{c}\text { Water intake } \\
\left(\mathrm{m} l / \mathrm{BW}_{\mathrm{kg}}{ }^{.75} / \mathrm{day}\right)\end{array}$} & \multicolumn{2}{|c|}{$\begin{array}{c}\begin{array}{c}\text { Urine volume } \\
\left(\mathrm{m} l / \mathrm{BW}_{\mathrm{kg}}{ }^{* 75} / \mathrm{day}\right)\end{array} \\
\end{array}$} & \multicolumn{2}{|c|}{$\begin{array}{l}\text { Fecal moisture } \\
\left(\mathrm{m} l / \mathrm{BW}_{\mathrm{kg}}{ }^{\cdot 75} / \text { day }\right)\end{array}$} \\
\hline & & M.S. & $\mathrm{F}$ & M.S. & $\mathrm{F}$ & M.S. & $\mathrm{F}$ \\
\hline Groups & 1 & 3340 & 4.53 & 2133 & $6.22 *$ & 5.35 & $6.29 *$ \\
\hline Treatments & 1 & 1200 & 1.63 & 1880 & $5.48^{*}$ & 0.54 & 0.64 \\
\hline Periods & 1 & 8683 & $11.77^{* * *}$ & 7621 & $22.22^{* *}$ & 0.00 & 0.00 \\
\hline Error & 8 & 738 & & 343 & & 6.82 & \\
\hline
\end{tabular}

Treatments

$\begin{array}{lccc}\text { Soy protein } & 114.8 \pm 13.8 & 80.6 \pm 14.2 & 12.8 \pm 2.0 \\ \text { Urea } & 134.8 \pm 52.9 & 105.7 \pm 45.3^{*} & 13.2 \pm 2.4\end{array}$

$* \mathrm{P}<.05 \quad * * * \mathrm{P}<.01$ 


\section{Effect of Urea on Water Metabolism}

Table 3. Analysis of variance of urinary osmotic pressure and hematocrit value, and average urinary $\mathrm{pH}$

\begin{tabular}{|c|c|c|c|c|c|c|}
\hline \multirow{2}{*}{$\begin{array}{l}\text { Source of } \\
\text { variation }\end{array}$} & \multirow[b]{2}{*}{ d.f. } & \multicolumn{2}{|c|}{$\begin{array}{l}\text { Urinary osmotic } \\
\text { pressure }\left(\mathrm{atm} . / 0^{\circ} \mathrm{C}\right)\end{array}$} & \multicolumn{2}{|c|}{$\begin{array}{c}\text { Hematocrit } \\
(\%)\end{array}$} & \multirow{2}{*}{$\begin{array}{l}\text { Urinary } \mathrm{pH} \\
\text { only available } \\
\text { in period II }\end{array}$} \\
\hline & & M.S. & $F$ & M.S. & $F$ & \\
\hline Groups & 1 & 22.0 & 2.86 & 6.83 & 0.31 & \\
\hline Treatments & 1 & 0.5 & 0.07 & 10.17 & 0.46 & \\
\hline Periods & 1 & 38.7 & 5.03 & 36.83 & 1.64 & \\
\hline Error & 8 & 7.7 & & 22.41 & & \\
\hline \multicolumn{7}{|l|}{ rreatments } \\
\hline Soy protein & & \multicolumn{2}{|c|}{$18.22 \pm 1.44$} & \multicolumn{2}{|c|}{$34.5 \pm 4.35$} & $6.20 \pm 0.64$ \\
\hline Urea & & \multicolumn{2}{|c|}{$17.80 \pm 4.27$} & \multicolumn{2}{|c|}{$36.3 \pm 4.27$} & $6.80 \pm 0.62$ \\
\hline
\end{tabular}

Table 4. Analysis of variance of urinary levels of calcium, magnesium and phosphorus

\begin{tabular}{|c|c|c|c|c|c|c|c|}
\hline \multirow{2}{*}{$\begin{array}{l}\text { Source of } \\
\text { variation }\end{array}$} & \multirow[b]{2}{*}{ d.f. } & \multicolumn{2}{|l|}{$\underset{(\mathrm{mg} / l)}{\text { Calcium }}$} & \multicolumn{2}{|c|}{$\begin{array}{l}\text { Magnesium } \\
(\mathrm{mg} / l)\end{array}$} & \multicolumn{2}{|c|}{$\begin{array}{c}\text { Phosphorus } \\
(\mathrm{mg} / l)\end{array}$} \\
\hline & & M.S. & $\mathrm{F}$ & M.S. & $F$ & M.S. & $F$ \\
\hline Groups & 1 & 352 & 0.07 & 280 & 0.17 & 4182 & 1.97 \\
\hline Treatments & 1 & 14 & 0.00 & 4408 & 2.63 & 75 & 0.04 \\
\hline Periods & 1 & 20254 & 3.91 & 40600 & $24.21 *$ & 22361 & $10.52^{* *}$ \\
\hline Error & 8 & 5184 & & 1677 & & 2126 & \\
\hline \multicolumn{8}{|l|}{ Treatments } \\
\hline Soy protein & \multicolumn{3}{|c|}{$133.7 \pm 46.2$} & \multicolumn{2}{|c|}{$275.7 \pm 61.1$} & \multicolumn{2}{|c|}{$78.2 \pm 43.8$} \\
\hline Urea & \multicolumn{3}{|c|}{$131.5 \pm 90.6$} & \multicolumn{2}{|c|}{$237.3 \pm 72.9$} & \multicolumn{2}{|c|}{$83.2 \pm 73.1$} \\
\hline
\end{tabular}

$* * \mathrm{P}<.01$

nesium in animals that received the isolated soy ration was considerably high. However, the difference was not significant.

\section{Discussion}

The effects of experimental periods on water intake and urine volume of wethers were remarkable in this experiment. These effects would be induced by the difference of the environmental factors such as ambient temperature $\left(17.6 \pm 1.8^{\circ} \mathrm{C}\right.$ and $\left.10.7 \pm 1.4^{\circ} \mathrm{C}\right)$ and humidity $(63.8 \pm 8.9 \%$ and $62.8 \pm 14.4 \%$ ) between the two experimental periods. Many workers ${ }^{10)}$ reported that the increase of water intake, which would perhaps introduce the increase of urine volume, was caused by the increase of ambient temperature in various ruminants. Some workers ${ }^{11}$ ) estimated the water intake as a function of ambient temperature. However, the principal theme in this experiment was not to study the effect of the environmental factors on water intake and urine volume, but to study the effect of dietary urea intake on water intake, urine volume and urinary mineral levels in the animals.

In the experiments carried out in the authors' laboratory, the occurrence of urolithiasis seemed to be few when the increased urine volume ${ }^{12)}$, the decreased urinary $\mathrm{pH}^{13)}$ and the low level of 


\section{Watanabe, Miyazaki and Kawashima}

urinary phosphorus ${ }^{13)}$ were observed in fattening steers on high concentrate rations.

In this experiment, the increased urine volume in the urea-fed animals reached to as much as $131 \%$ of that in the animals which were not given urea ration. The authors supposed that the increased urine volume in the urea-fed animals would have some relations with the occurrence of urolithiasis in ruminants.

Urinary $\mathrm{pH}$ was slightly higher in the urea-fed animals. Though administration of ammonium chloride was known ${ }^{14)}$ to be effective in the prevention of urolithiasis of magnesium phosphate type by decreasing urinary $\mathrm{pH}$ of the animals on high concentrate rations, effects of urea intake on the prevention of urolithiasis seemed to be introduced by increasing urine volume. The fact that urea was osmotic diuretics and ammonium chloride was acidifying diuretic ${ }^{33}$, would be responsible for the different effects on the prevention of urolithiasis between them.

The effect of urea intake on urinary levels of calcium, magnesium and phosphorus was not apparent, since large variations were observed among the individual animals. However, it was remarked that urinary levels of calcium and phosphorus did not decrease when urine volume increased in the urea-fed animals.

The effect of urea intake on these urinary features in this experiment was considerably different from that of ammonium chloride administration, which became a common practice in fattening program of beef cattle.

It was also remarked that water intake increased in the urea-fed animals by $17 \%$ over the control. Since dry matter consumption, which was known ${ }^{10)}$ to affect water intake in ruminants, was almost equal between soy protein lot and urea lot in this experiment, this increase of water intake in the urea-fed animals seemed not to be caused by the difference of dry matter consumption, but to be affected by the difference of the ingredient of the experimental rations. UESAKA et al. ${ }^{12)}$ reported that fattening steers on urea ration consumed more water, though no detailed data were available, than those on non-urea ration in a feedlot. PRICE et al. ${ }^{15)}$ reported that a significant linear increase $(P<.05)$ was observed for water intake of wether lambs when the level of urea increased in purified diet. They also reported that water intake of wether lambs on the isolated soy ration in the same experiment was $50 \%$ more than that of the animals on urea ration containing the same amounts of nitrogen. These results seemed to suggest the possibilities that feeding nitrogen-rich ration would be effective for the prevention of urolithiasis by increasing urinary excretion of water in ruminants.

In ruminants, protein in the ration was known to be readily degraded to ammonia in the reticulo-rumen. ${ }^{16)}$ Ammonia produced in the reticulo-rumen was absorbed rapidly into blood vessel and transported to liver. ${ }^{17)}$ In this organ, ammonia was converted to urea, which was normally not harmful substance in blood of the animals. ${ }^{18)}$ When urea was intraruminally given to the ruminants, it was readily degraded to ammonia in the reticulo-rumen, which was fated to be utilized in the same way as ammonia that was the reduction product of dietary protein. In ruminants, urea intake and protein intake, therefore, would have the same effects on nitrogen metabolism, so far as the amounts were optimum. In some experiments, it was observed that steers on a high protein intake consumed more water (up to $26 \%$ more) than similar animals on low protein ration ${ }^{10)}$. Therefore, the increase of water intake induced by the increase of urea level in the ration might be a result of the increase of nitrogen level in the ration. In this experiment, crude protein level of urea ration was $2.6 \%$ higher than that of soy protein ration. The difference of crude protein levels between the isolated soy ration (crude protein 14.1\%) and the urea ration (crude protein 16.8\%) might introduce, to some degree, the increased water intake in this 
experiment.

The authors supposed that diuretic effect of urea in ruminants seemed to be certain, though considerably weak, because the percent increment of urine volume by feeding urea ration containing $2.25 \%$ urea was as much as $31 \%$.

Urea has been known to be one of the osmotic diuretics ${ }^{3)}$. However, in this experiment, no apparent effect of urea intake was observed, so far as urinary osmotic pressure of wethers was determined. It was because the amount of urea given to the animals was not large enough to show drastic diuretic effect. The same explanation would be possible on hematocrit value, which has been known to be an indicator for osmotic pressure of blood in the animals. The fact that the animals ingested water at free choice might have some effects on small differences of urinary osmotic pressure and hematocrit between the urea-fed animals and the soy-protein-fed animals. From the results of the experiment, the effect of urea intake on the prevention of urolithiasis, reported by Kawashima et al. ${ }^{2}$, seemed to be introduced by the increased excretion of urine, not by other factors such as the changes of urinary $\mathrm{pH}$ or urinary levels of minerals, which have been known to have relation with the occurrence of urolithiasis of magnesium phosphate type of ruminants on high concentrate ration in Japan. Therefore, it is important to study the interaction among the protein levels in ration, blood urea levels and the amounts of drinking water in ruminants.

The relationship between water intake and urine volume was also remarkable in this experiment. A significant correlation $(\mathrm{r}=0.931, \mathrm{P}<.01)$ between water intake and urine volume per metabolic body size per day was found in the combined data for the animals. The equation describing this relation was U.V. $=0.189$ W. $1 .+68.97$, where U.V. and W. I. $=$ urine volume $(\mathrm{m} l)$ and water intake $(\mathrm{ml})$ per metabolic body size of the animal per day. This equation will be useful in estimating urine volume of sheep with considerable accuracy, when a precise determination for water intake is possible under the similar experimental conditions.

\section{References}

1) ReID, J. T., J Dairy Sc1 36: 955-996. 1953.

2) Kawashima, R., J. Saita, M. Niyama, and S. Uesaka, Bull Anim Nutr Kyoto Univ 2: 6-8. 1973.

3) Kato, E., and M. Yamauchr, Taieki Balance no Kiso to Rinsho 290-336. Bunkodo. Tokyo. 1971. (in Japanese)

4) Packetr, L. V., and J.P. Hauschild, J Nutr 84: 185-190. 1964.

5) KanaI, I., and M. KanaI, Rinsho Kensaho Teiyo VI 22-23. Kanehara Shuppan. Tokyo. 1968. (in Japanese)

6) Watanabe, H., Thesis for Bachelor of Kyoto Univ. 1974.

7) SAME JimA, J., Butsuri-Kagaku Jikkenho 15th ed. 227-232. Shokabo. Tokyo. 1949. (in Japanese)

8) Fiske, C. H., and Y. Subbarow, J Biol Chem 66: 375-400. 1925.

9) Yoshida, M., Design of Experiments for Animal Husbandry 101-116. Yokendo. Tokyo. 1975.

10) Church, D. C., Digestive Physiology and Nutrition of Ruminants 2: 401-416. OSU Book Stores Inc. Oregon. 1971.

11) Winchester, C.F., and M. J. Morris, J Anim Sci 15: 722-740. 1956.

12) Uesaka, S., R. Kawashima, K. Namikawa, J. Saita, T. Ando, T. Yamauchi, K. Mitsuno, A. Inoue, and H. InuI, Res Bull No. 42 of Takahara Exp Sta Kyoto Univ. 1972.

13) Uesaka, S., R. Kawashima, K. Namikawa, and G. Mishiro, Res Bull No. 28 of Takahara Exp Sta Kyoto Univ. 1967.

14) Yano, H., R. Kawashima, and S. Uesaka, Mem Coll Agric Kyoto Univ. No. 101: 27-34. 1972. 
15) Price, W. D., J. A. Brown, E. E. Menvielle, and W. H. Smith, J Anim Sci 35: 848-853. 1972.

16) Dougherty, R. W., Physiology of Digestion in the Ruminant 322-334. Butterworths. London. 1965.

17) McDonald, I. W., Biochem J 42: 584-587. 1948.

18) Swenson, M. J., Dukes' Physiology of Domestic Animals 8th ed. 579-580. Cornell Univ. Press. Ithaca. 1970.

\title{
尿素の経口投与がめん羊の飲水量，尿量および 尿中ミネラル濃度に及ぼす影響
}

\author{
淓辺晴彦・宮崎昭・川島良治
}

京都大学農学部, 京都本 606

\begin{abstract}
肥育牛に尿菜を含む飼料を与えたとき，尿石症の発生 が少ない傾向のあることが観察さ机ている。そこで后石 症に対する尿素の作用を確かるるために，めん羊を用い て尿素給与時の水分代謝と尿中ミネラル嶩度を模討し た. めえ年6頭它 2 区（でいずたん白質区と尿索区）に 分け，予備期 14 日間，試験期 10 日間上りなる 2 期につ いて，ラテン万格法に上る試験を行った。試験期間中に は飲水量, 尿量, 䔬中水分量, 尿の $\mathrm{pH}$, 尿の浸透王, 血 液のへマトクリット值, 尿中の Ca, Mg 拈よび $\mathrm{P}$ 濃度 を測定し，その結果を分散分析した。无の結果，䧕駼の 時期間に有意差 $(P<.01)$ 認めたか，尿素給与の影徨
\end{abstract}

のみ老調ベたところ, 代謝体重当たりの尿量は尿素給与 時に $31 \%$ 堌加し $(\mathrm{P}<.05)$, 飲水量は $17 \%$ 増加した。一方, 䔬中水分量, 尿の漫透压, 血液の一マトクリット值, 尿 の $\mathrm{pH}$ ，尿中のCa乱よ゙ P濃度に恃尿菜給与による影

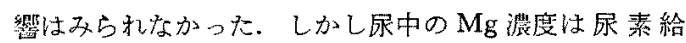
与時にやや低办った。 そのため，尿素の給与性飲水量子 尿畾增加させることによって尿石症の発生を予防する のではないかと思わ机た。なお，本試験ではめん羊の代 謝体重当たりの饮水量と尿量との間には，r=0.931 とい

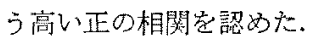

